\title{
Chemical Transportation of Heavy Metals in the Constructed Wetland Impacted by Acid Drainage
}

\author{
Keiko Sasaki ${ }^{1}$, Tagiru Ogino ${ }^{2}$, Osamu Hori ${ }^{3}$, Yuji Endo ${ }^{2}$, Kunihiko Kurosawa ${ }^{2}$, Masami Tsunekawa $^{3}$ \\ ${ }^{1}$ Laboratory of Environmental Science, Otaru University of Commerce, Otaru 047-8501, Japan \\ ${ }^{2}$ Geological Survey of Hokkaido, Sapporo 060-0819, Japan \\ ${ }^{3}$ Graduate School of Engineering, Hokkaido University, Sapporo 060-8628, Japan
}

\begin{abstract}
Chemical transportation of heavy metals in the constructed wetland impacted by acid drainage was investigated seasonally using a combination of the selective sequential extraction of the sediments with elemental analysis of the emergent vegetation in the wetland. Manganese was dissolved from sediments in the constructed wetland by the contact with acid drainage, and then precipitated again as ionexchangeable forms. It was expected that a part of $\mathrm{Mn}$ and Fe bound to oxides were flown out of the wetland as suspended particulate matters. It was observed that there is passive absorption of $\mathrm{Mn}$ in leaves of Phragmites austlaris in the upstream of the wetland. The transportation of Cu clearly showed the seasonal variation: there was the decomposition of organic substances with high molecular weights by soil microorganisms in summer. Therefore, $\mathrm{Cu}$ was complexed to the humic substances, and dramatically adosorbed onto the roots of Phragmites austlaris in down stream of the wetland. It was also observed that there is active absorption of Fe in roots and leaves of Phragmites austlaris. Most of the zinc was strongly bounded to the sediments, therefore, scarcely uptaken to the vegetation. It was also found that there were heavy metal distributions between plant organs.
\end{abstract}

(Received September 4, 2002; Accepted November 8, 2002)

Keywords: acid drainage, constructed wetland, water treatment, heavy metals, Phragmites austlaris, sequential extraction

\section{Introduction}

The wetland is the integrated natural system consisting of underlying strata, hydric soils, detritus, water, and emergent vegetation. The standing water provides a habitat for aquatic organisms including fish and vertebrate animals, submerged and floating plant species, living algae and populations of microbes. The wastewater treatment is proceeded by remediation potential of each component and their interaction. Macrophytic plants provide much of the visible structure of wetland treatment system. There is no doubt that they are essential for the high levels of water quality improvement by means of evapotranspiration, transportation of oxygen to soils, providing a habitat for microbes in addition to the uptake, sorption of harmful substances, decomposition, and filtration. Wetland soils have a high trapping efficiency for a variety of chemical constituents, based on the abilities of cation-exchange, chelation of heavy metals, sorption and chemical decomposition of harmful substances. Soil microbial populations have significant influence on the chemistry of wetland. Important transformations of nitrogen, iron, sulfur, and carbon result from microbial processes. The mirobial processes are typically affected by the concentrations of reactants as well as the redox potential and $\mathrm{pH}$ of the soil.

Constructed wetlands mimic the optimal treatment conditions found in natural wetlands but provide the flexibility of being constructable at almost any location and can be used for treatment of waste waters. ${ }^{1)}$ The use of constructed wetlands as biogeochemical systems for the treatment of acid mine drainage has developed rapidly over the last few decades in North America and Europe. ${ }^{2-6)}$ The wetland treatment has an advantage of low cost, low energy, and maintenance-free, as compared with chemical treatment by utilization of the ecological system. The treatment of various metal-mine drainage water is a small but a growing application area for constructed wetlands. ${ }^{7)}$

In the present work, we constructed the plant-size of wetland in the place where the acid Mn-rich drainage occurred under the construction of a dam, in order to investigate the water quality at outlet of the wetland, and the seasonal variations of the adsorption and accumulation of heavy metals to soil sediments and the emergent plants. This is the first application of the constructed wetland to the treatment of acid drainage in Japan.

\section{Field Description and Samples}

\subsection{Field description}

Water chemistry of acid drainage out of building a dam in the south of Hokkaido, Japan is as follows: Mn $121.05 \mathrm{mg} / \mathrm{L}$, $\mathrm{Fe} 18.08 \mathrm{mg} / \mathrm{L}, \mathrm{Cu} 6.77 \mathrm{mg} / \mathrm{L}, \mathrm{Zn} 3.84 \mathrm{mg} / \mathrm{L}, \mathrm{Cd} 0.066 \mathrm{mg} / \mathrm{L}$, $\mathrm{pH} 3.17$, as measured in May 2000. The high contents of Mn and low $\mathrm{pH}$ are characteristic of this water. The wetland was constructed in October 2000, which has $6 \mathrm{~m}$ in width, $16 \mathrm{~m}$ in length, and $1 \mathrm{~m}$ in average depth. An overview of the wetland is shown in Fig. 1. To prolong the residence time of drainage, several detours were installed in the wetland. The residence time was around one month. The flow rates of drainages were

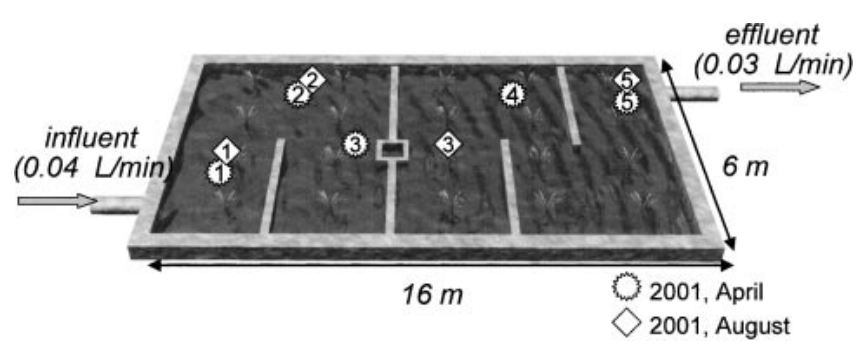

Fig. 1 Overview of the constructed wetland in the present work. 
$0.04 \mathrm{~L} / \mathrm{min}$ at inlet and $0.03 \mathrm{~L} / \mathrm{min}$ at outlet on an average. The sand and lime stones were laid in the bottom and soil sediments were covered on them. Phragmites australis, which is representative to emergent vegetation, was implanted there. Acidic drainages have been introduced from 20th October 2000 to 31th August 2001, but temporarily stopped from the end of December 2000 to the beginning of April 2001, due to the frost damage in winter season.

\subsection{Samples}

The flow rates, $\mathrm{pH}$, temperature, electronconductivity of drainages were automatically measured at inlet and outlet using a multi-water quality monitoring system U-22 (Horiba, Co. Ltd. Japan) at the field through the experimental term. Water samples were taken at inlet and outlet in the wetland every twice a week to analyze the concentrations of heavy metals and was carried to the laboratory with cooling.

Sediment samples were taken from one site in the constructed wetland before the introduction of drainages, from 5 sites along the stream in April 2001 (before the 2nd introduction), from 4 sites in August 2001. Sampling sites were numbered from upstream to downstream as shown in Fig. 1.

Vegetation samples were taken from one site before the introduction of drainage, and three sites in August 2001. In the end of experiments in August 2001, there were a lot of the withered plants, Phragmites australis.

\section{Analytical Methods}

\subsection{Water analysis}

Sampled waters were acidified to $\mathrm{pH} 1$ with $\mathrm{HCl}$, and filtered to analyze dissolved $\mathrm{Fe}, \mathrm{Mn}, \mathrm{Cu}, \mathrm{Zn}$, and $\mathrm{Cd}$ concentrations by a Hitachi Z-6100 Atomic Adsorption Spectrometry.

\subsection{Sequential extraction of sediments}

Sediment samples were roughly de-hydrated at $40^{\circ} \mathrm{C}$ for $72 \mathrm{~h}$ in a vacuum drier. The dried samples were ground to collect -100 mesh fractions by sieving and sent for XRF analysis and sequential extraction for heavy metals.

This method has been applied for river sediments in which labile and weakly bounded species of heavy metals are included. ${ }^{8)}$ One gram of dried sediment was extracted in $8 \mathrm{~mL}$ of $1 \mathrm{~mol} \mathrm{~L} \mathrm{~L}^{-1} \mathrm{MgCl}_{2}$ (pH 7.0) for $5 \mathrm{~h}$ at room temperature. In this step, exchangeable species are extracted. Second, the residue was extracted in $8 \mathrm{~mL}$ of $1 \mathrm{~mol} \mathrm{~L}^{-1}$ $\mathrm{NaOCOCH}_{3}(\mathrm{pH} \mathrm{5.0)}$ for $5 \mathrm{~h}$ at room temperature to release the species bound to carbonate. Third, the residue was extracted in $20 \mathrm{~mL}$ of $0.04 \mathrm{~mol} \mathrm{~L}^{-1} \mathrm{HONH}_{3} \mathrm{Cl}$ in $25 \%(\mathrm{v} / \mathrm{v})$ $\mathrm{HO} \mathrm{COCH}_{3}$ for $6 \mathrm{~h}$ at $96^{\circ} \mathrm{C}$ to release the species bound to $\mathrm{Fe}-\mathrm{Mn}$ oxides. Next, the residue, which was bound to organic matter, was extracted in $30 \mathrm{~mL}$ of $0.02 \mathrm{~mol} \mathrm{~L}^{-1} \mathrm{HNO}_{3}$ and $5 \mathrm{~mL}$ of $30 \% \mathrm{H}_{2} \mathrm{O}_{2}\left(\mathrm{pH} 2.0\right.$ with $\mathrm{HNO}_{3}$ ) for $2 \mathrm{~h}$ at $85^{\circ} \mathrm{C}$ in $3 \mathrm{~mL}$ of in $30 \% \mathrm{H}_{2} \mathrm{O}_{2}$ for $3 \mathrm{~h}$ at $85^{\circ} \mathrm{C}$ after cooling in $5 \mathrm{~mL}$ of $3.2 \mathrm{~mol} \mathrm{~L}^{-1} \mathrm{NH}_{4} \mathrm{O} \mathrm{COCH}$ in $20 \%$ (v/v) $\mathrm{HNO}_{3}$ for $30 \mathrm{~min}$ at room temperature.

The final residues were decomposed by a microwave decomposer Mile Stone ETHOS PLUS. The $0.5 \mathrm{~g}$ of residual sample was taken from the residue and thrown into a teflon vessel, where $7 \mathrm{~mL}$ of conc. $\mathrm{HNO}_{3}, 2.5 \mathrm{~mL}$ of $49.5 \% \mathrm{HF}$, and $0.5 \mathrm{~mL}$ of $30 \% \mathrm{H}_{2} \mathrm{O}_{2}$ were added. The cap of teflon vessel was tightly set in a decomposer. Samples were decomposed by keeping at $210^{\circ} \mathrm{C}$ for $20 \mathrm{~min}$ after heating with $8^{\circ} \mathrm{C} / \mathrm{min}$ of the rising rate of temperature. The sample was completely decomposed by this procedure and diluted for ICP-AES analysis.

In the process of sequential extraction, the obtained leachate in each extraction was filtrated by membrane filter with $0.2 \mu \mathrm{m}$-pore size to determine the $\mathrm{Fe}, \mathrm{Zn}, \mathrm{Cu}$, and $\mathrm{Mn}$ concentrations by an ICP-AES SPS 7800 (SEIKO, Co. Ltd.).

\subsection{Heavy metal distributions in Phragmites australis}

Sampled plants were washed by tap water to remove the adsorbed soil particles, divided to roots, stems, and leaves. After cutting into 3-5 cm-size, they were washed by distilled water again, dried in a drying oven at $85^{\circ} \mathrm{C}$ for $72 \mathrm{~h}$, ground again to be powdery, and then dried again in an oven at $85^{\circ} \mathrm{C}$ for $4 \mathrm{~h}$, followed by cooling in a dessicator. A $0.25 \mathrm{~g}$ of each part was added to a teflon vessel containing $3 \mathrm{~mL}$ of $65 \%$ $\mathrm{HNO}_{3}, 0.5 \mathrm{~mL}$ of $30 \% \mathrm{H}_{2} \mathrm{O}_{2}, 0.25 \mathrm{~mL}$ of $40 \% \mathrm{HF}$. The vessels were installed in an ETHOS PLUS microwave, and the samples were completely decomposed by keeping at $200^{\circ} \mathrm{C}$ for $20 \mathrm{~min}$ after heating at the rate of $6.7^{\circ} \mathrm{C} / \mathrm{min}$. The product was diluted by using the $100 \mathrm{~mL}$-mess flask made of teflon. After filtration by membrane filter with $0.2 \mu \mathrm{m}$ pore size, the Fe, $\mathrm{Al}, \mathrm{Zn}, \mathrm{Cu}, \mathrm{Mn}, \mathrm{P}, \mathrm{K}, \mathrm{Na}$, and $\mathrm{Ca}$ concentrations were determined by ICP-AES.

\section{Results}

\subsection{Changes in water chemistry before and after wet- land treatment}

Figures 2(a)-(f) show the changes in dissolved $\mathrm{Mn}, \mathrm{Fe}, \mathrm{Cu}$, $\mathrm{Zn}$, and $\mathrm{Cd}$ concentrations at the inlet and outlet in the constructed wetland. There are blank parts between December 2000 and April 2001 due to water freezing in winter season. Except for $\mathrm{Fe}$ concentrations, it is difficult to recognize the pronounced difference at the inlet and outlet between in any metal ion concentration. Hence, these data were converted to transported amounts per day (gram/day) using flow rates, as shown in Fig. 3. Transported amounts per day (gram/day) are defined by the loading amounts multiplied the concentrations by flow rates per day. It was found that in any metal ion the transported amount was smaller at outlet than at inlet, suggesting that in particular these heavy metal ions seem to be accumulated in the wetland in early term from October to December 2000.

\subsection{Seasonal variations in chemical forms of heavy metals fixed to sediments in the processes of wetland treatment}

Selective extractions of three sediments were carried out, which were sampled in October 2000 (before the draining of acid water), April 2001 (at re-draining), and August 2001 (just before the stop draining), respectively. Figures 4-7 present the results of selective extraction for $\mathrm{Mn}, \mathrm{Fe}, \mathrm{Cu}, \mathrm{Zn}$ in sediments, in which the vertical axis indicates the amount of each fraction expressed by $\mathrm{mg} / \mathrm{one} \mathrm{kg}$-dry sediment, the horizontal axis is correspondent to the number of sampling 
(a)

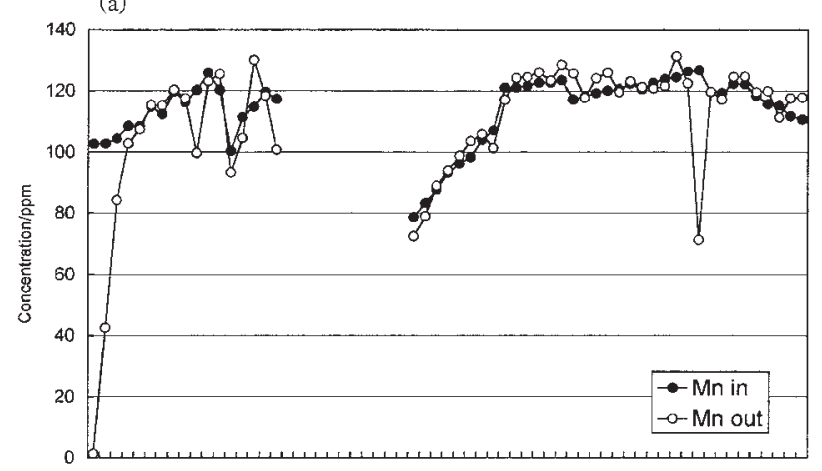

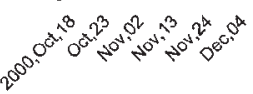
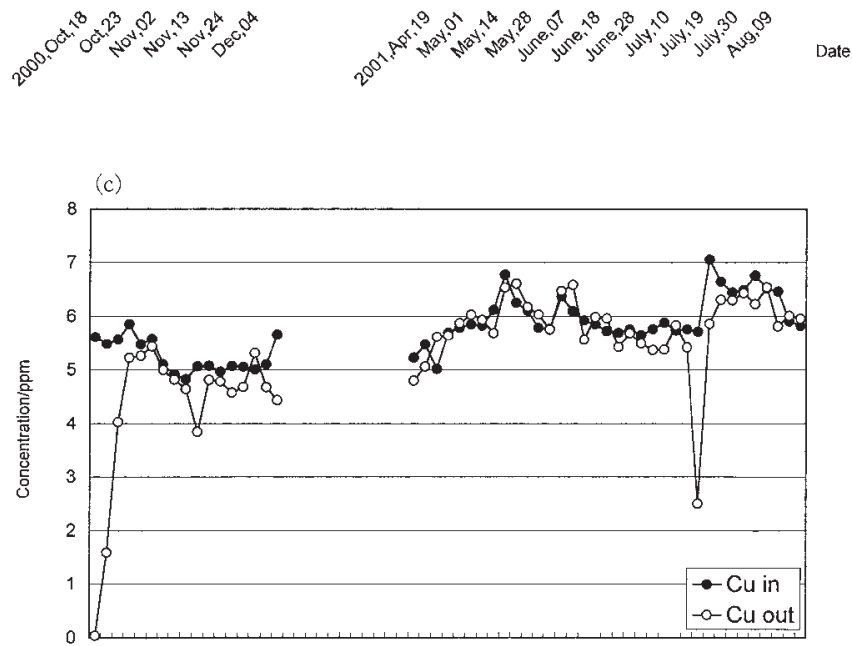

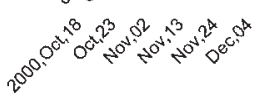

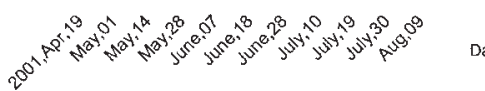

Date
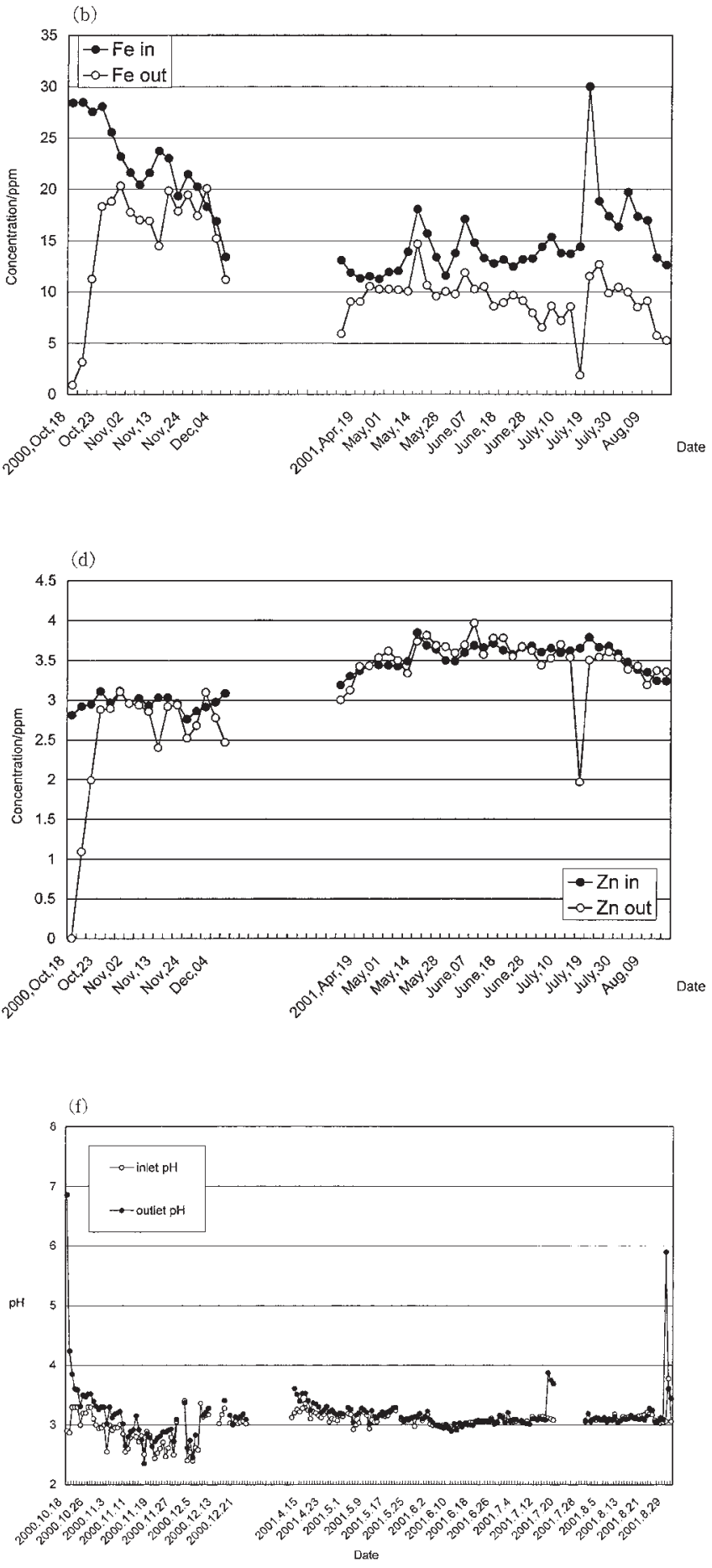

Fig. 2 Variation of the concentrations (mg/L) of (a) $\mathrm{Mn}$, (b) $\mathrm{Fe}$, (c) $\mathrm{Cu}$, (d) $\mathrm{Zn}$, (e) $\mathrm{Cd}$ and (f) pH at inlet and outlet of the wetland.

site in Fig. 1, and the "initial" means the values in October 2000. There are five and four sampling sites in April 2001, and August 2001, respectively, which are numbered in order from upstream. It was assumed that the components of the sediment were uniform, independent of site in the wetland, during October 2000 before the draining of acid water.

Initially, Mn was mainly the oxide-bound type ('initial' in Fig. 4(a)). In April 2001, they were partly dissolved by the impact of acid drainage in the sites 1 and 2 (upstream) and changed to ion-exchangeable type. In August, 2001, the replacement from oxide-bound type to ion-exchangeable type was enhanced all over the wetland, resulting the content of ion-exchangeable type attained to be mostly equal to that of oxide-bound type (Fig. 4(b)). Total content of Mn in sediment seems to have decreased during April to August 2001.

The $\mathrm{Fe}$ accounts the highest in heavy metal content in sediment $(\sim 23 \mathrm{~g} / \mathrm{kg})$. As shown in 'initial' of Fig. 5(a), the fraction of 'residue' was the highest, followed by the fraction of oxide-bound. It indicates that the strongly bounded types are mainly for $\mathrm{Fe}$. The compositional change of $\mathrm{Fe}$ in the sediment was not clearly observed even after leading acid 

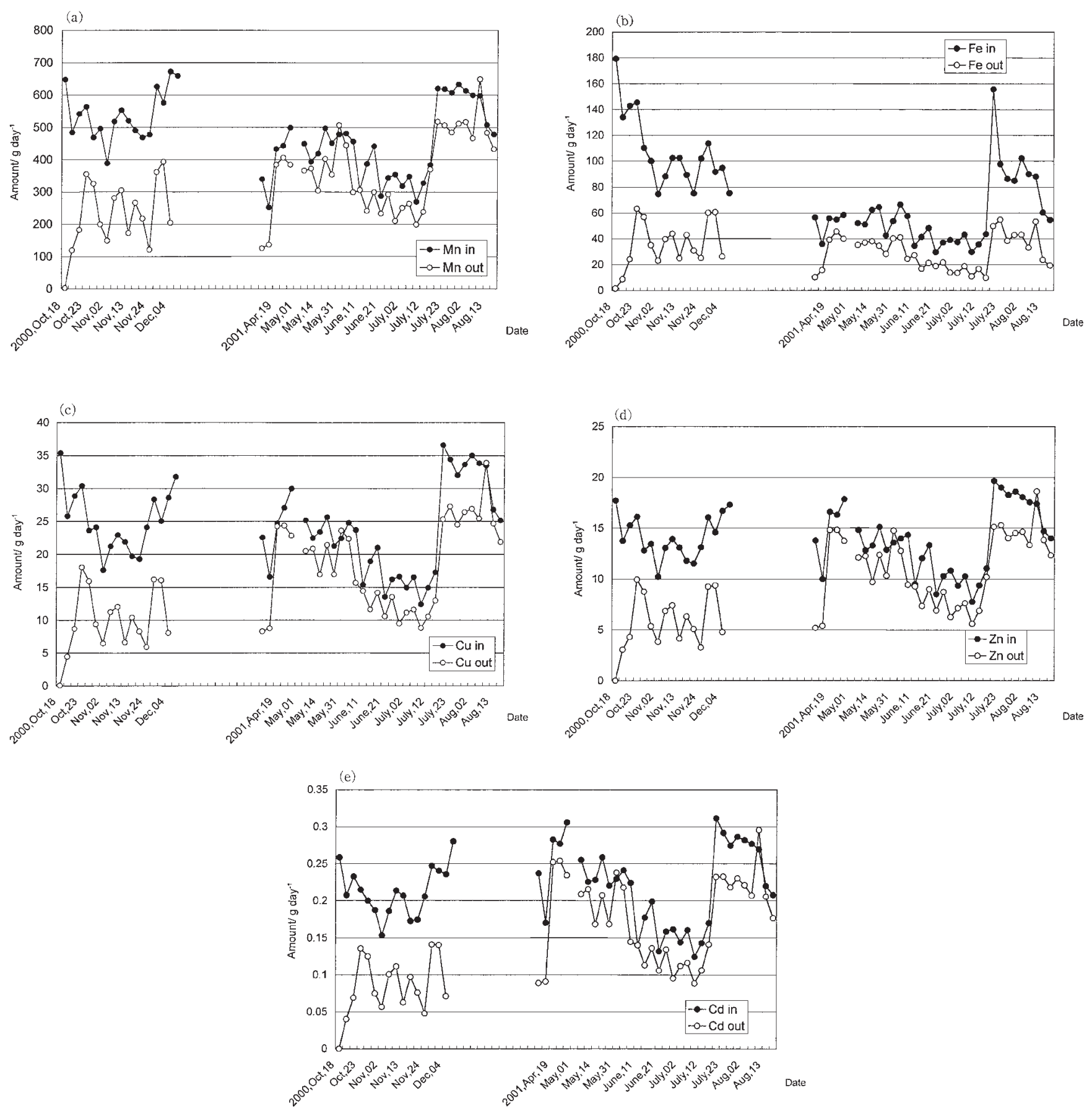

Fig. 3 Variation of the transported amounts (g/day) of (a) $\mathrm{Mn}$, (b) $\mathrm{Fe}$, (c) $\mathrm{Cu}$, (d) $\mathrm{Zn}$ and (e) $\mathrm{Cd}$ at inlet and outlet.

water to the wetland (Figs. 5(a), (b)). Total content of Fe in the sediment has decreased by $1-4 \mathrm{~g} / \mathrm{kg}$ in August 2001 .

There were not observable for $\mathrm{Cu}$ content in the initial sediment of the wetland ('initial' of Fig. 6(a)). Even after 2 month-leading acid water, i.e., in April 2001, the trend was not changed (Fig. 6(a)). However, a dramatic increase in $\mathrm{Cu}$ content was observed at the site 2 of Fig. 1 in August 2001 (Fig. 6(b)). In particular, the content of the fraction bound to organic matters attained to $150 \mathrm{mg} / \mathrm{kg}$ of dry sediment.

The initial $\mathrm{Zn}$ content was determined to be $25 \mathrm{mg} / \mathrm{kg}$ of dry sediment mainly as the fraction bound to oxides, and few in the other fractions ('initial' of Fig. 7(a)). In April 2001, the fraction 'the residue' has increased to reach equal or much more level to the fraction of oxide-bound type (Fig. 7(a)). In
August 2001, the fractions of weakly bound types of $\mathrm{Zn}$ were almost not observed, therefore, the re-dissolution of fixed $\mathrm{Zn}$ species was not expected. Total content of $\mathrm{Zn}$ in the sediment has decreased from April to August 2001.

\subsection{Uptake of heavy metals in Phragmites australis}

The contents of (a) Mn, (b) Fe, and (c) Cu involved in leaf, stem, and root of Phragmites australis before and after treatment of acid drainage are shown in Fig. 8, with the average and standard deviation of all the three analyses. The standard deviations were relatively small in all the cases. This indicates that the heavy metal accumulation in vegetation is mostly constant with narrow distribution at the specific spot in the wetland. The Fe ions were accumulated in leaves and 

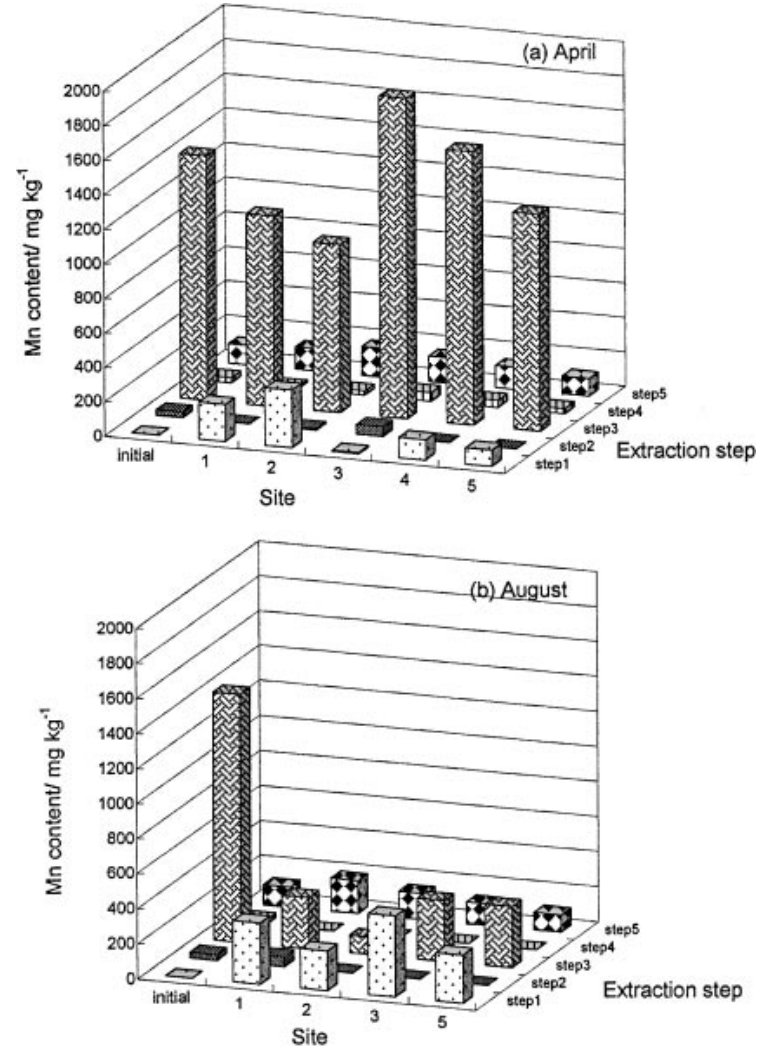

Fig. 4 Contents of sequentially extracted Mn from sediments taken from the constructed wetland in (a) April 2001, (b) August 2001. 'Initial' means October 2000. Step 1, ion-exchangeable; step 2, carbonate-bound; step 3, oxide-bound; step 4, organic matter-bound; step 5, the residue.
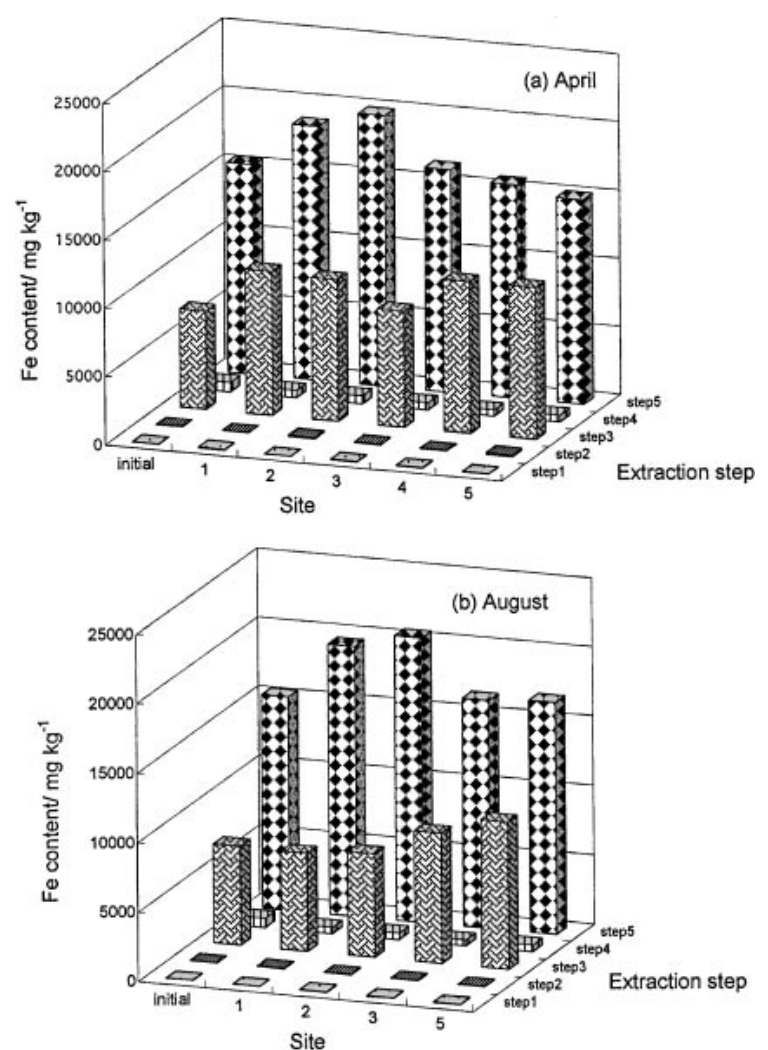

Fig. 5 Contents of sequentially extracted Fe from sediments taken from the constructed wetland in (a) April 2001, (b) August 2001. 'Initial' means October 2000. Symbols are the same as in Fig. 4.
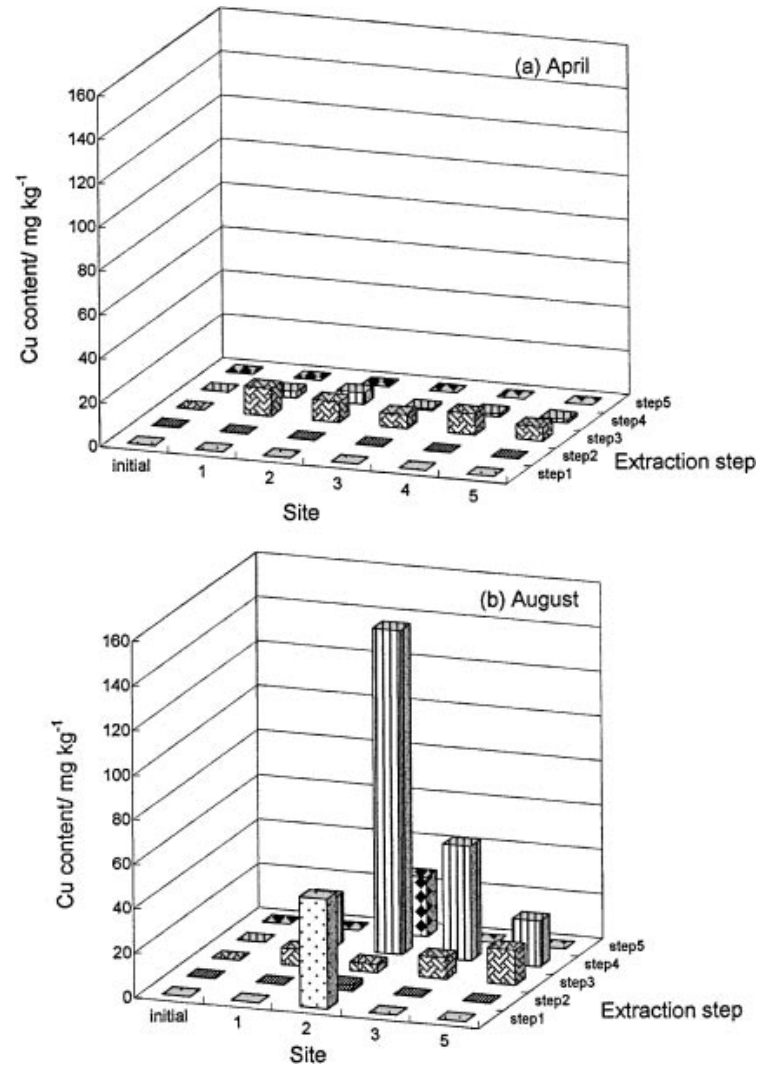

Fig. 6 Contents of sequentially extracted $\mathrm{Cu}$ from sediments taken from the constructed wetland in (a) April 2001, (b) August 2001. 'Initial' means October 2000. Symbols are the same as in Fig. 4.
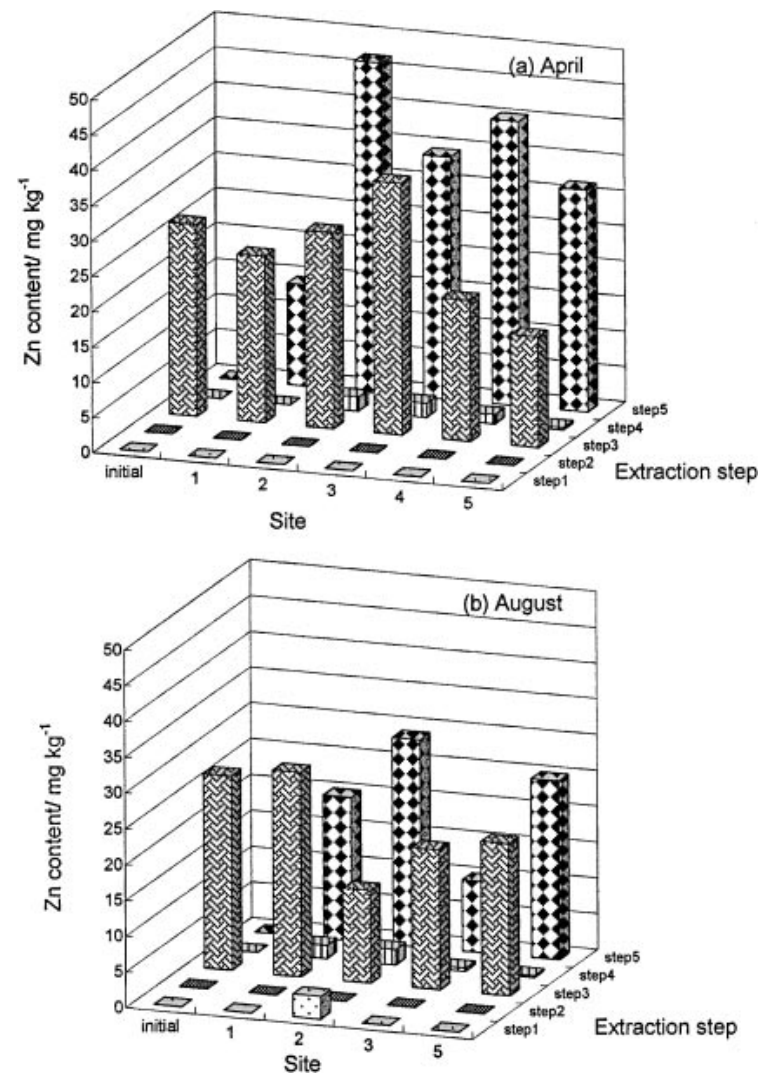

Fig. 7 Contents of sequentially extracted $\mathrm{Zn}$ from sediments taken from the constructed wetland in (a) April 2001, (b) August 2001. 'Initial' means October 2000. Symbols are the same as in Fig. 4. 


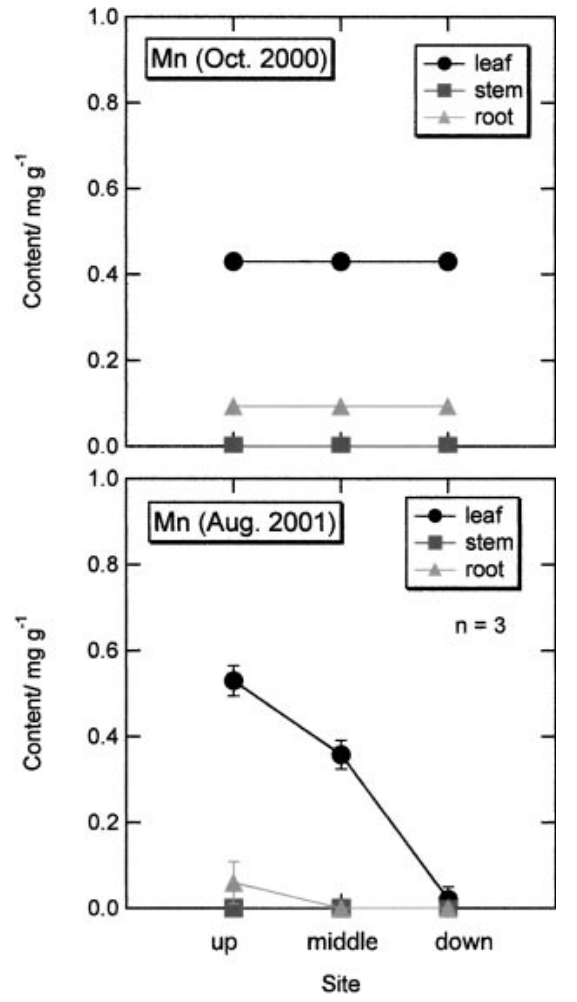

(a)

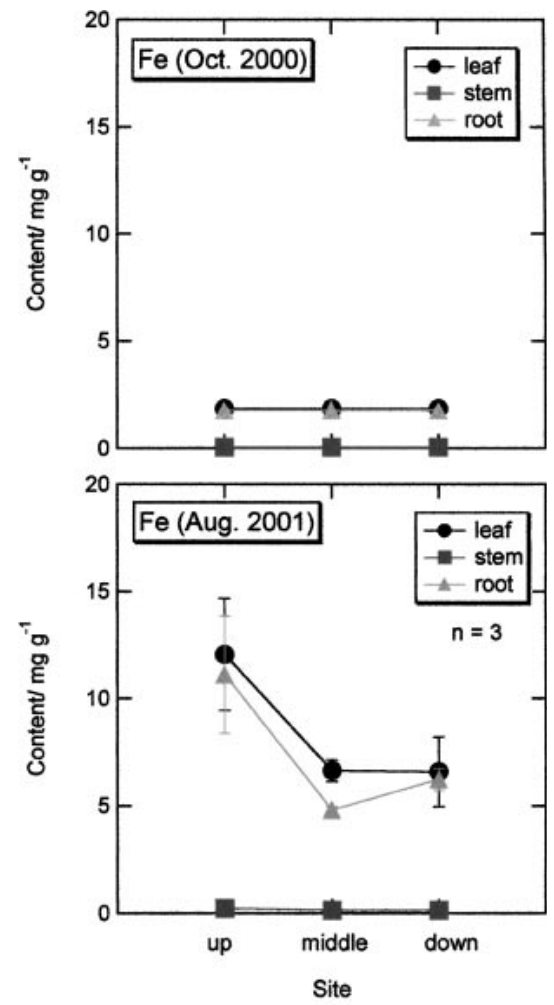

(b)

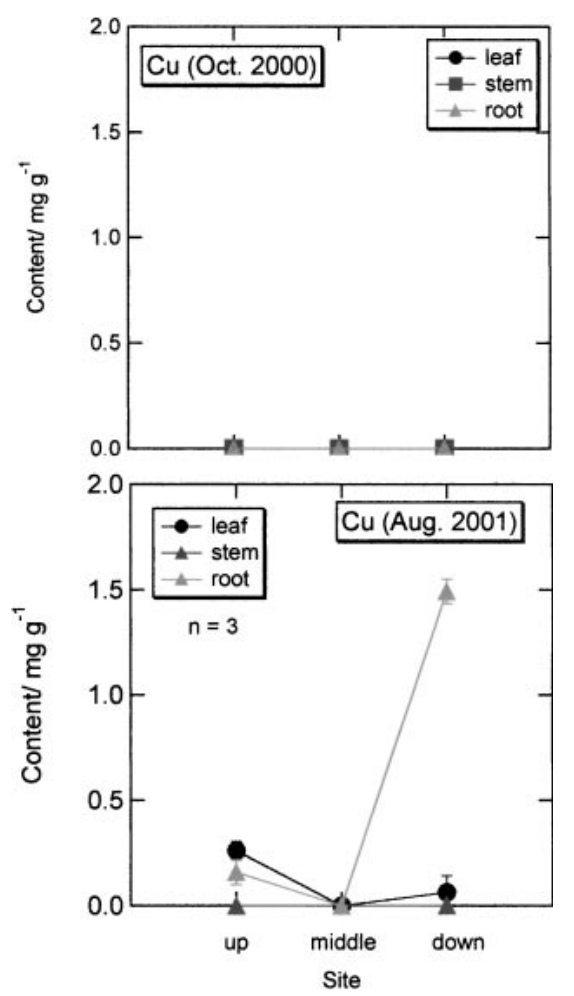

(c)

Fig. 8 Contents of heavy metals, (a) Mn, (b) Fe, (c) Cu in Phragmites australis taken from the constructed wetland in October 2000 and August $2001(n=3)$.

roots of $P$. australis, with twice the amounts in upstream parts than other parts (Fig. 8(b)). The Mn ions were accumulated in leaves of $P$. australis in the upstream parts of the wetland, and that of $\mathrm{Cu}$ ions were accumulated in roots of $P$. australis in the downstream (Fig. 8(c)). These three metal ions were accumulated in leaves or roots, and passed through the stem. Analysis of $\mathrm{Zn}$ ions was also carried out, but results indicated that it was under the detection limit for all samples.

The contents of other elements, (a) Na, (b) K, (c) Al, (d) $\mathrm{Ca}$, and (e) $\mathrm{P}$ involved in leaf, stem, and root of $P$. australis before and after treatment of acid drainage are shown in Fig. 9. The standard deviation was large in common. The average was mostly constant independent of any part in the wetland. Except that $\mathrm{Na}$ and $\mathrm{Al}$ contents had increased, the essential elements were not changed by leading acid drainage to the constructed wetland.

\section{Discussion}

Neither increase in $\mathrm{pH}$ nor decrease in the dissolved $\mathrm{Mn}$ concentrations was observed during the period from October 2000 to August 2001, therefore, the preliminary purpose was not achieved. However, there are various changes in chemical transformations and bioaccumulation of heavy metals in $P$. australis and sediments in the wetland. These are reflected to the biogeochemical changes of heavy metals related to seasonal variation of ecological system in the wetland.
Initially, the Mn content was about $1.4 \mathrm{~g} / \mathrm{kg}$-dry sediment which mainly consists of oxide-bound type. By contact with acid drainage, a part of sediment in upstream was dissolved and then bound to sedimentary particles as an ion-exchangeable type. The dissolved Mn concentrations did not dramatically change during the experimental period. Converting the concentration into the amounts of Mn by using the flow rate, it was found that there was the positive load in the wetland. In August 2001, the total Mn content was calculated to be 800$900 \mathrm{mg} / \mathrm{kg}$-dry sediment. That is, $500-600 \mathrm{mg} / \mathrm{kg}$ of Mn was lost in the wetland during April to August 2001. However, the dissolved Mn concentrations did not increase, therefore, the re-dissolution of $\mathrm{Mn}$ is highly improbable.

The Fe also mainly occurs as stable forms in the sediment, as shown in Fig. 5. Around 1-4 g/kg-dry sediment of Fe was lost in the wetland during April to August 2001, though there were differences depending on the site of the wetland. Though around $10 \mathrm{mg}$ Fe/g-vegetation was uptaken by $P$. australis, they are not released from the oxide-bound form in sediment but from the dissolved iron in acid drainage. It is considered that the oxide-bound $\mathrm{Fe}$ and Mn flowed out of the wetland as suspended particulate matters.

The behavior of $\mathrm{Cu}$ ions was quite different from those of $\mathrm{Mn}$ and $\mathrm{Fe}$ ions. The $\mathrm{Cu}$ content was scarcely observed in the initial sediment. In summer, heterotrophic microorganisms grow actively with increase in temperature and decompose the high molecular organic substances to low molecules such as humic substances, which easily form complexes with $\mathrm{Cu}$ (II) ions. It is considered that the complexes of $\mathrm{Cu}(\mathrm{II})-$ 


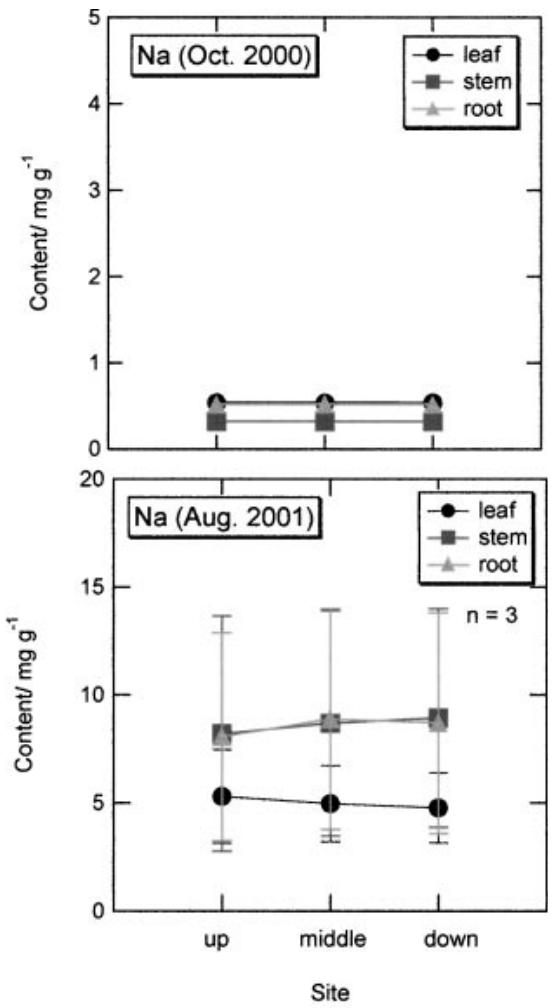

(a)

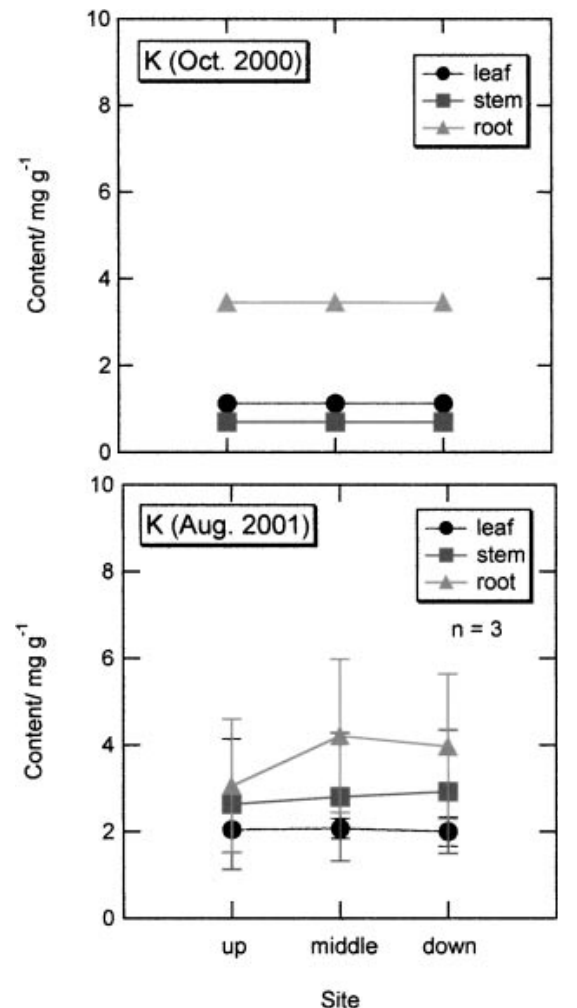

(b)

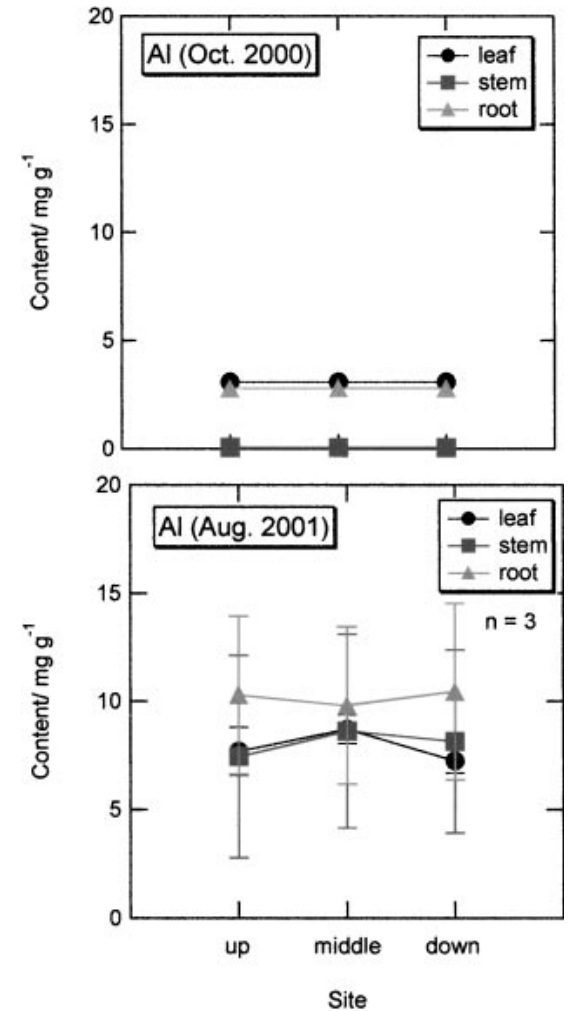

(c)

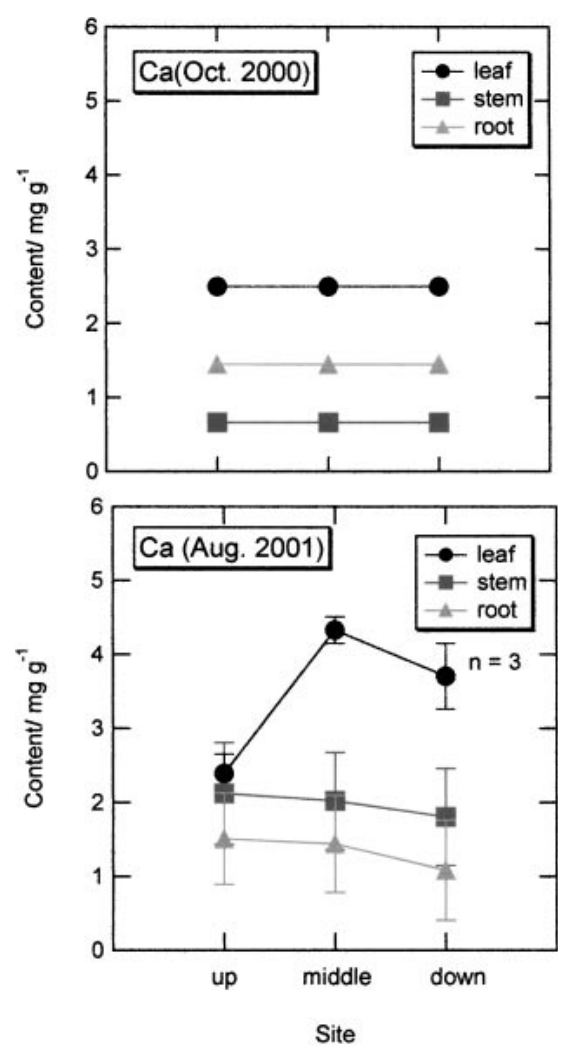

(d)
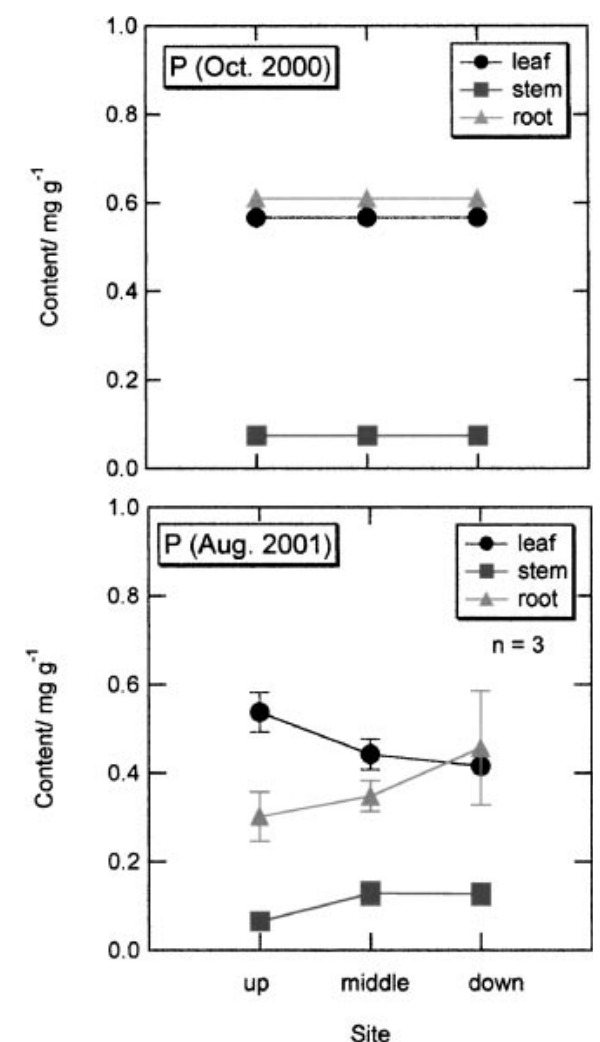

(e)

Fig. 9 Contents of other elements, (a) Na, (b) K, (c) Al, (d) Ca, (e) P in Phragmites australis taken from the constructed wetland in October 2000 and August $2001(n=3)$. 
organic substances were polymerized to fix in the sediments. It is well known that the stability constant for the complex of $\mathrm{Cu}$ (II) ions and humic substances is large. ${ }^{9)}$ A part of the complex might be uptaken into the roots of $P$. austlaris in the downstream of the wetland. The Cu-uptake markedly occurred in spite of low $\mathrm{Cu}$ (II) concentrations in the drainage, therefore, it would be a kind of 'active' transportation, different from that of $\mathrm{Mn}$ case. The $\mathrm{Fe}, \mathrm{Cu}$, and $\mathrm{Mn}$ are necessary for plant metabolism as enzyme activators or regulators, which become toxic if supplied in excess. ${ }^{10)}$ Aluminum (Al) is also one of the most potent toxic metals for plant growth in acidic soils. It has been reported that Altolerant plants excrete more organic acids than the Alsensitive plants. ${ }^{11)}$ In addition, humic substances, which were much produced in summer, might lead the chelation with $\mathrm{Al}$ to mitigate the inhibition of plant growth.

It was observed that the $\mathrm{Zn}$ content was under the detection limit in P. austlaris in both seasons. Because the element has already become the most stable in April 2001 (Fig. 7(a)), it is assumed to be difficult for the plant to uptake.

On the contrary of $\mathrm{Cu}$, it was not observed that $\mathrm{Mn}$ (II) ions were actively absorbed to $P$. austlaris. The Mn-uptake seems to be only 'passive'. It was reported that a subtle cooperation between $\mathrm{Fe}$ and $\mathrm{Cu}$ is certainly 'synergistic' which means plant growth was diminished under the multiple metal stress, comparing with separate supply. ${ }^{12)}$ For effective removal of $\mathrm{Mn}$, it would be necessary to set the preliminary pond in series to remove the dissolved Fe ions by aeration, followed by the main pond loading with low concentrations of other heavy metal ions for microbial oxidation of $\left.\mathrm{Mn}(\mathrm{II}) .{ }^{13}\right)$

\section{Conclusions}

In the experimental period, $\mathrm{Mn}$ ions were dissolved by contact of sediments with acid drainage, and fixed in the sediment as unstably bounded forms, that is, an ionexchangeable type. The replacement occurred in order from the upstream of the wetland. Based on decrease in dissolved heavy metal ions and changes in total $\mathrm{Mn}$ and Fe-contents in the sediment, the eliminating route was estimated. The dissolved $\mathrm{Mn}$ and Fe ions get precipitated as the suspended particulate matters consisting of oxide-bounded Fe and Mn to remove away out of the wetland system by the flow of drainage.

There was the passive accumulation of $\mathrm{Mn}$ in leaves of $P$. australis in the upstream of the wetland in the periods. In summer, the living microorganisms grow actively with increase in temperature and decompose the high molecular organic substances to low molecules such as humic substances, which easily form complexes with $\mathrm{Cu}$ (II) ions to fix as the organic matter-bound type in the sediments. A part of the $\mathrm{Cu}$-complexes was actively uptaken into the roots of $P$. austlaris in the downstream of the wetland. Also Fe species were actively accumulated in roots and leaves of $P$. austlaris. It is assumed to be difficult for the emergent vegetation to absorb $\mathrm{Zn}$ species, because the element has already become the most stable in initial several months. In summary, it was recognized that the accumulation of heavy metals is specific to parts of the emergent vegetation, and that the accumulation of heavy metals was constant to the weight of an individual, independent of the contents of essential elements in itself.

\section{Acknowledgments}

This work was partly supported by a Grant-in-Aid for Scientific Research (No. 13555275) from the Japan Society for the Promotion of Science (JSPS).

\section{REFERENCES}

1) C. D. Barton and A. D. Karathanasis: Environ. Geol. 39 (1998) 39-50.

2) P. A. May and G. S. Edwards: Ecol. Enging. 16 (2001) 487-500.

3) J. D. F. Robinson and G. A. Robb: Coal Intl., July (1995) 152-156.

4) T. Manyin, F. M. Williams and L. R. Stark: Ecol. Enging. 9 (1997) 171-185.

5) F. J. Sikora, L. L. Behrends, G. A. Brodie and H. N. Taylor: Water Environ. Res. 72 (2000) 536-544.

6) R. K. Wieder: Wetlands 9 (1989) 299-315.

7) B. N. Noller, P. H. Woods and B. J. Ross: Wat. Sci. Technol. 29(4) (1994) 257-265

8) A. Tessier, P. G. C. Campbell and M. Bisson: Anal. Chem. 51 (1979) 844-851.

9) M. Fukushima, S. Tanaka and M. Taga: J. Chem. Soc. Japan, No. 5 (1991) 556-558

10) Z. Krupa, A. Siedelecka, E. Skorzynska-Polit and W. Maksymiec: Physiology and Biochemistry of Metal Toxicity and Tolerance in Plants, (Kluwer Academic Publishers, Dordrecht, 2002) pp. 287-301.

11) H. Matsumoto: Physiology and Biochemistry of Metal Toxicity and Tolerance in Plants, (Kluwer Academic Publishers, Dordrecht, 2002) pp. 95-109.

12) E. D. Harris: Nutr. Rev. 52 (1994) 311-319.

13) K. Sasaki, M. Endo, K. Kurosawa and H. Konno: Mater. Trans. 43 (2002) 2773-2777. 